\title{
Gender Equality in Elementary Education: A Dream or Reality
}

\author{
Parvaiz Ahmad Dar \\ Department of Education, Central University of Kashmir (J\&K), India
}

\begin{abstract}
For centuries girls were not treated equal to boys in many ways. The education of girls has become one of the most important concerns of 21 st century not only at local level but also at the national level. Efforts by the government are on to ensure gender equality but government initiatives alone would not be sufficient to achieve this goal. Society must take initiative to create a climate in which there is no gender discrimination and girls have full opportunity to receive good quality elementary education without any barrier. The female literacy rate is also lower than the male literacy rate. The ground reality is deprivation and exploitation of girls especially from rural areas and those belonging to deprived sections of the society. Education is a powerful tool of social transformation. Hence, education for girls has to be paid special attention. Greater access for education must be ensured in the educational system. Gender sensitivity must be developed. A watch has to be kept on dropout rate of girls and corrective measures should be taken to check the dropout rates. There is no denying the fact that education of girls have made considerable progress in almost every aspect, but they still have to struggle against many handicaps and social evils in the male dominated society. The study found that there are 222 children in the age group of 06-14 years who are out of school from a single education zone. Taking this thing into consideration it seems a dream to achieve $100 \%$ literacy rate at elementary level if time bound steps are not taken to solve this problem. Hence, the study will help all stakeholders to become aware of the present situation and issues prevailing in the education zone Khag and can play an active role in solving these problems effectively and fruitfully.
\end{abstract}

Key Terms: Gender Equality, Elementary Education

\section{Introduction}

"Everyone has the right to education. Education shall be free, at least in the elementary and fundamental stages. Elementary education shall be compulsory.... Education shall be directed to the full development of human personality and to the strengthening of respect for human rights and fundamental freedoms." (Universal Declaration of Human Rights, Article 26)

To achieve the Millennium Development Goals (MDG) there is a need to tackle the alarming problem of out of school children (OOSC), especially in developing countries. India has launched several programs to reach the remotest corners of the country; however, the issue of equity, quality, enrolment, retention, infrastructure, and learning achievement of children remains a neglected area. No matter the enrolment has increased, but at the same time dropout level is growing respectively at the primary and elementary level. The serious concern of the present times is that different sources show different figures of OOSC in India, which does not reveal the true picture. The data presented by various sources is questionable when compared with each other. In India, a significant number of children remain OOSC, especially from low-income families, marginalized sections of society, and mostly girls.

\section{II.Preface of Research}

As it is a common belief, particularly in rural areas, that education of girls is not of much importance as his prime job is to perform household activities. Some of them show great interest in studies but ends up being marginalized due to this particular notion of parents. So there is a need to tackle the obstacle of gender discrimination. So keeping these things into consideration, there is an urgent need to fill these gaps, whether it is an economic gap, social gap, gender gap, enrolment gap, or learning gap.

Due to the several social and political disturbances in Kashmir valley, the condition of the education sector is very poor, because it lacks proper educational planning and infrastructure. In recent years the government with the help of central government try their best to bring an improvement in the field of education by launching many program, projects, and policies. The school education ladder is bifurcated into Primary, Middle, Secondary, and Higher Secondary stages. "The school education is undoubtedly one of the largest departments under the $\mathrm{J} \& \mathrm{~K}$ government, but the same is administratively so poor that one can take it as nothing more than a transfer industry and GP fund office. There are various loopholes in the administrative setup of this department for which government is least bothered about" (Shah, H: p110). "The government is trying to take various initiatives from time 


\section{Yinternational Research Journa!}

p-ISSN 2202-2821 e-ISSN 1839-6518 (Australian ISSN Agency)

to time to improve the education system. The government runs many centers and state-supported schemes, especially for the backward/underprivileged sections of the society, so that they are not deprived of education. It includes providing free education up to the college level, mobile institutions for the nomadic population, scholarships, free books, and uniform to deserving students." (Galgotra, M. 2015). (J\&K Government Report, 2007) "Identified 1.07 lakh out of school children in the age group of $6-11$ years, $4.60 \%$ of the children are out of school children whereas $7.85 \%$ of ST children and $10.15 \%$ of ST girls are out of school in this age group. In the 11-14 age groups, $8.19 \%$ of children are out of school, whereas $20.15 \%$ of ST children and $26.09 \%$ of ST girls are out of school in this age group. Kupwara, Budgam, Srinagar, Anantnag and Doda have the highest proportion of out of school children".

The literacy rate of $\mathrm{J} \& \mathrm{~K}$ as per census 2011 is 68.74 percent, which is below the national average literacy rate, which is 74.04 percent. The economic survey report of 2016-2017 presented in the legislative assembly has shown a decreasing trend in the out of school children. As per the report, in the year 2015-2016, the total number of OOSC in J\&K was 79598 children who have noticeably decreased to 54713 in 20162017. The report also revealed that the number of out of school girls has decreased from 46218 in 2015-2016 to 31856 in 2016-2017. While as the report shows an increasing trend in the dropout rate of primary and upper primary school children from 6.93 percent and 5.36 percent in the year 2015-2016 to 10.30 percent and 10.20 percent in the year 2016-2017.

\section{A. Education zone Khag}

Khag is blessed with deep valley and breath-taking sceneries. It is a town, Municipal committee, and headquarters of the Budgam District. It is located 34 kilometres away from Srinagar. As per census 2011, the literacy rate in tehsil khag is $38.31 \%$ which is far below than literacy rate at district level (57.98\%), state-level (67.16\%) and national level (74.04\%). Education zone Khag has a number of educational institutions from primary to higher secondary level. Almost 114 government and private schools of nearly 35 villages come under the education zone of Khag. Education zone Khag starts from village Bamurada to Sitharn. Zone Khag is distributed in 08 clusters, which are: Khag, Khanpora, Poshker, Panziyari, Shunglipora, Hamchipora, Khud Lassipora, and Bamurada.

\section{B. Rationale of the study}

The present study is very useful because it sheds light on different aspects of the study. The importance and progress of elementary education are being highlighted in many programs, policies, reports, and research studies, but no such study has been conducted in the education zone khag. Therefore, the
Vol. 12 No. 012022

828012012022187 (C) Author(s)

present study has opened up a new direction in this respect. The problem which has been identified by the investigator will give a proper track to the authorities concerned in developing and modifying the programs and policies regarding the education of children at the elementary level.

\section{Objectives of the Study}

The present study is framed based on the following objectives:

- To find out the total number of children in the age group of 06-14 years who have never been enrolled in school.

- To find out the total number of children in the age group of 06-14 years who got dropout from the school.

- To find out the total number of out of school children in the age group of 06-14 years.

\section{Review of Related Literature}

In the present chapter, the investigator attempts to analyse the previously existing piece of documented literature regarding out of school children available through various sources. This chapter includes the review on main categories such as demographic status of OOSC, determining factors contributing children to be out of school, implications of children being out of school, the current situation of OOSC, parental perception on the education of OOSC,

The investigator has gone through a few studies conducted in Jammu and Kashmir, India and abroad related to the area the overview of the studies are as under:

- Hazarika, G., Bedi and Arjun, S. (2010), Seetharaman, A.S., \& Ushadevi, M.D. (2008), Sharma, R., Sharma S., \& Nagar, S. (2007) and Dreze, J. and Gazdar. H. (1996) studied that illiteracy and low education of the parents is a factor for out of school children.

- Combining Data on Out-of-school Children (2019), Global initiative on out-of-school children (2018), Din, et al. (2011), Mukherjee, D. (2011), Naval, F.J.G (2009) Jeyaraj, D., and Subramanian, S. (2005), Govindaraju, R., and Vasavi and Mehendale, A. (2003) studied that poverty of parents is a big hurdle in the way of education of children which directly or indirectly give rise to the problem of OOSC.

- Farooq, M.S. (2013) found that the most reported reason for out of school children was the boring teaching style, physical punishment fear of teacher, lack of essential facilities in schools and unattractive school atmosphere. 
- Child labor is also mentioned in the studies of Sinha, S. (2000), and Bauddha, V. (1997) as a factor for nonenrollment and drop out of children from school.

- Family-related reasons are also seen in the studies of Huisman J., \& Smits, J. (2012), Khan, G.A., Tahir, M., \& Shah, S.A. (2011), Goswami, A.S. (2009),. Kotwal, N., Neelima, \& Rani, S. (2007) and Sharma, 2007 as a factor which influences the dropout or non-school going children.

- Gender differences are also seen in the studies of Khan, S., \& Pandey, G. (2012), Li, D., \& Tsang. M.C (2002) in which the dropout rate of girls is more than boys.

\section{Methodology}

The choice of methods for research work depends upon the nature of the problem selected. Mainly methodology consists of tools, techniques, and procedures. The success of the investigation depends on the priority of the method and the tools and techniques the researcher uses.

\section{A. Locale of the study}

The present study is carried out in education zone Khag of district Budgam Jammu and Kashmir.

\section{B. Research design}

In the present study, a descriptive survey method of research is used by the investigator in order to know about the OOSC in education zone Khag.

\section{Sampling Design}

Non Probability sampling was used for the present study.

\section{Sample and sampling technique}

The sample for the present study consists of 222 OOSC children and their parents. A purposive sampling technique was used to collect the data from the respondents.

\section{Tools used for data collection}

The following tools were employed in the present study for data collection.

\section{Interview schedule-I (for out of school children)}

Interview schedule-II (for parents of out of school children)

\section{Analysis and Interpretation of Data}

The present article provides analysis and interpretation of the field level data collected from parents, out of school children, community, and from other sources. The investigator was guided by an interest in understanding the total number of OOSC in the age group of 06-14 years.

Table 1: Number of dropout from school

\begin{tabular}{|c|c|c|c|}
\hline Age & Boys & Girls & Total \\
\hline 6 to 11 & 10 & 15 & 25 \\
\hline 11 to 14 & 82 & 63 & 145 \\
\hline Total & 92 & 78 & 170 \\
\hline
\end{tabular}

If we analyze the table 1 carefully, we will find that out of 170 dropout cases, the number of boys was 92 while the number of girls is 78. One of the important things to consider is that more girls $(60 \%)$ than boys $(40 \%)$ were dropped out at the primary stage, while more boys (57\%) as compared to girls (43\%) were dropped out at the upper primary stage. The dropout rate is more at the upper primary stage as the majority (85.29\%) of the dropout children are in the age group 11-14 years whereas only $(14.17 \%)$ of the dropout children are in the age group of 06-11 years.

Table 2: Showing the number of children who were never enrolled in school

\begin{tabular}{|c|c|c|c|}
\hline Age & Boys & Girls & Total \\
\hline 6 to 11 Years & 09 & 21 & 30 \\
\hline 11 to 14 years & 04 & 18 & 22 \\
\hline Total & 13 & 39 & 52 \\
\hline
\end{tabular}

During the survey, the investigator found 52 such children in the education zone, Khag, who had never been enrolled in any type of school. The table 2 show that out of 52 children that have never been enrolled in schools, 39 are girls, and the remaining 13 are boys. With the total estimated out of school children, $52(23.4 \%)$ have never been enrolled in any school. The above table gives a clear indication that the percentage of girls $(75 \%)$ that were never enrolled is much higher than boys (25\%).

Table 3: Showing total number of out of school children

\begin{tabular}{|l|c|c|c|}
\hline Age & Boys & Girls & Total \\
\hline 6 to 11 & 19 & 36 & 55 \\
\hline 11 to 14 & 86 & 81 & 167 \\
\hline Total & 105 & 117 & 222 \\
\hline
\end{tabular}

The table 3 shows that the total number of OOSC in the age group of 06 to 14 years is 222 , out of which 117 are girls and 105 are boys. In the age group of 06 to 11 years, 55 children are OOS, and the remaining 167 children who are out of school fall in the age group of 11 to 14 years. Disaggregating gender-wise $(52.70 \%)$ of girls are OOS as compare to $(47.29 \%)$ of boys. Within the age group of 6-11 years, $(65.45 \%)$ of girls are OOS as compared to $(34.54 \%)$ of boys in the same age group. In the age group of 11-14 years $(48.50 \%)$ of girls and (51.49\%) of boys are OOS. 
Yinternational Research Journal

p-ISSN 2202-2821 e-ISSN 1839-6518 (Australian ISSN Agency)

Table 4: Willingness of parents to send OOSC to school

\begin{tabular}{|l|l|l|}
\hline Willingness & Number & Percentage \\
\hline Interested & 121 & $54.50 \%$ \\
\hline Not interested & 82 & $36.93 \%$ \\
\hline Undecided & 19 & 8.55 \\
\hline Total & 222 & $100 \%$ \\
\hline
\end{tabular}

The table 4 shows that majority (54\%) of parents are interested to send their out of school children to school and $(37 \%)$ of parents are not willing for the same. However, $(9 \%)$ of parents have not yet decided whether to enroll their children in schools or not.

\section{Major Findings of the Study}

Based on the analysis and interpretation presented in the previous chapter, one gets the idea that education zone Khag progressed enormously; however, it has some areas of concern, which are mainly responsible for the un-fulfilment of the goals of universalization of elementary education. Findings which are coming after analysing and interpreting the data are:

1) The dropout rate is higher at the upper primary stage, which is $85.30 \%$, and to some extent, it is less in the primary stage, which is $14.70 \%$.

2) $60 \%$ of girls drop out at the primary stage as compared to $40 \%$ of boys.

3) The number of boys is more than girls in case of dropout at the upper primary stage, which is $57 \%$ of boys as compared to $43 \%$ of girls.

4) Out of the total number of OOSC, it was found that never enrolled children constitute $23.42 \%$ of children who are out of school.

5) The number of girls that are never enrolled is much higher than boys. The percentage of girls is $75 \%$ as compared to $25 \%$ of boys.

6) Disaggregating gender-wise $(52.70 \%)$ of girls are OOS as compare to $(47.29 \%)$ of boys.

7) The majority (54\%) of the parents are interested in sending their OOSC to school, and $(37 \%)$ of the parents are not willing. Whereas, $(9 \%)$ of parents were undecided about the education of their children.

8) The study found that dropout is more among poor students as compared to higher economic class students.

9) Due to unfavorable circumstances in Kashmir valley, schools remain frequently closed, which directly or indirectly affects the quality of the education system.
Vol. 12 No. 012022

828012012022187 (c) Author(s)

\section{Suggestions}

For the achievement of the target of M.D.G. and E.F.A. of universal enrolment, it is not simply important to enrol children in school, but it is also important to ensure that they complete elementary schooling.

1) School dropout and non-school going is a very complex phenomenon, a very dangerous one, but it happens too much easily and frequently. It is a very complex problem with a mixture of different factors responsible for expanding this issue. A comprehensive approach is required to tackle these issues as well as to improve the socio-economic conditions which contribute to the problem.

2) Regular schools with an inclusive orientation are the most important means of fighting discrimination, creating welcoming communities, building an inclusive society, and achieving education for all. Moreover, these schools will provide effective education to the majority of children and improve efficiency and, ultimately, the cost-effectiveness of the entire education system.

3) Illiteracy and ignorance among a sizeable population of adults is also a contributory factor for their indifferent mindset towards their children's schooling. Extensive awareness programs, especially in hilly areas and tribal areas, should be carried out on a regular basis to highlight the value of education for every child. More voluntary organizations may be engaged in this area to establish close linkage with the community, which is heterogeneous and diverse. The private sector should view it as a collaborator rather than a competitor.

4) Out-of-school is a multifaceted phenomenon. The identification of out-of-school children and the motivation of their parents should be planned carefully. A campaign should be set to let all people know about the related educational policies as well as the benefits of education to the children and to society.

5) The environment of the school plays a significant position in generating the interest of the students towards education. Thus, the school's environment should be made propitious with the availability of adequate infrastructure facilities and proper buildings. 
6) Special bridge courses must be started to create interest and familiarize never-enrolled and dropout children towards education.

7) The government should provide Special scholarship schemes to low-income families who will motivate them to send their children to schools regularly until they complete elementary education. Parents of children working in low salaried occupations will be covered under this scheme. Theses should be provided to the children in order to tackle socioeconomic factors. Incentives may also be introduced for those poor children who are regular and performing well.

8) Prime priority should be given to the removal of illiteracy among girls, and, in this regard, the community can play an active role in enrolling and retaining OOSC in schools.

9) Parent-teacher meetings should be organized at regular intervals for developing mutual understanding and discussing the performance of children.

\section{Conclusion}

In line with the commitment to provide good quality elementary education to all children, the education system does not do enough justice. Zone khag has remained educationally backward despite various initiatives undertaken by the government from time to time. So, the government and voluntary sector should highlight the importance of education at the elementary level and make efforts to encourage children of low-income families especially girls to pursue good quality elementary education without any impediments. Underprivileged families must be specially educated with a proper social formula to help them as a foundation for empowerment. New schemes and educational programs for OOSC, mainly residing in far-flung areas, should be implemented at the grass-root level.

The investigator observed that no one is going to blame himself for his faults. Most of the parents responded that educational factors and lack of interest of the child in studies are responsible for the child being out of school. In contrast, majority of the teachers blame that the negligence of parents is responsible for children being out of school. When the same question was asked to OOSC, they responded that Poverty, education not considered necessary by parents, and schoolrelated factors are responsible for it.

\section{References}

[1]. Din, et al. (2011). Causes of Male dropout rate in Pakistan. Journal of College teaching and learning, 8 (4), 37-42.

[2]. Dreze, J. \& Gazdar, H. (1996). "The Burden of Inertia", in Dreze \& Amartya Sen (eds), Indian Development: Selected Regional Perspectives. New Delhi: Oxford University Press.

[3]. Farooq, M.S. (2013). An inclusive schooling model for the prevention of dropout in primary schools in Pakistan, Bulletin of Education and Research, 35 (1), pp.47-74.

[4]. Galgotra, M. (2015) a causative study of dropouts and non-school going children in Jammu, Thesis submitted to the Department of Education, University of Jammu. 20. Government of Jammu and Kashmir. (2015-16). Economic Survey, Directorate of Economics and Statistics, Srinagar.

[5]. Goswami, A.S. (2009). Study on reasons for dropping out from schools. published by Tomorrow's Foundation.

[6]. Govindaraju, R. \& Venkatesan, S. (2010). A study on school dropouts in rural settings, Kamla Raj Journal of Psychology. 1 (1), pp. 47-53.

[7]. Huisman, J. \& Smits, J. (2012). Keeping children in school: Nice working paper, Nijmegan Center for Economics (NICE), Institute for Management Research, Radboud University, Nijmegan.

[8]. Jammu \& Kashmir State Resource Centre (2009). First half yearly Report on SSA and MDM, University of Kashmir, Hazratbal, Srinagar.

[9]. Jayaraj, D. \& Subramanian, S. (2005). Out of School and (probably) in Work, Child Labour and Capability Deprivation in India, UNU-WIDER (United Nations University-World Institute for Development Economics Research), Research Paper No. 2005/55.

[10]. Khan, G.A., Tahir, M. \& Shah, S.A. (2011). Gender dimensions of dropout in basic education in Pakistan: A Probity Analysis, European Journal of Social Sciences, 24(1), 121-133.

[11]. Khan, S. \& Pandey, G. (2012). Causal factors of School dropouts: A study of Aligarh District, U.P. International Journal of Research in Social Sciences, vol. 2 (1), pp.236-241

[12]. Kiplimo, G. and Amunga, H. (2021) "Women's Participation in Governance and Political Processes in Kenya: Threats and Proposed Remedies", IARS' International Research Journal. Victoria, Australia, 11(2), pp. 46-54. doi: 10.51611/iars.irj.v11i2.2021.173. 
[13]. Kotwal, N., Neelima, \& Rani, S. (2007). Causes of school dropouts among rural girls in Kathua district, Kamla Raj Journal of Human and Ecology, vol.22 (1), pp.57-59

[14]. Mukherjee, D. (2011). Reducing out of school children in India: Lessons from a micro study, Retrieved from http://www.dise.in/Downloads/ Use\%20of \%20Dise\%20 Data/ Dipa\%20Mukherjee.pdf.

[15]. Naik, J.P. (1966). Elementary Education in India the unfinished business. Asia Publishing House, Bombay.

[16]. National Sample Survey (2014). Estimation of out-ofschool children in the age group of 6-13years in India, Social and Rural Research Institute, IMRB International. Educational Consultants India Ltd. (Edcil). Retrieved from http://www.india-seminar.com /2018/706/706_rukmini_banerji.htm.

[17]. National Sample Survey (2014). Estimation of out-ofschool children in the age group of 6-13years in India, Social and Rural Research Institute, IMRB International. Educational Consultants India Ltd. (Edcil). Retrieved from http://www.india-seminar.com /2018/706/706_rukmini_banerji.htm.

[18]. Naval, F.J.G. (2009). Factors in school leaving: Variations across Gender groups, School levels, and Locations, Educational Quarterly, vol.67(1), pp.62-78

[19]. Seetharaman, A.S. \& Ushadevi, M.D. (2008). Education in Rural Areas. New Delhi: Ashish Publishing House, pp. 15-17.

[20]. Shah, H. (2018). School Education in Jammu and Kashmir: Issues and Concerns, Educational Quest: An Int. J. of Education and Applied Social Science. vol. 9(1), pp.107-113.

[21]. Sharma S. C. (2007). Women's Education: key to prosperity, Women Link, Jan- March, pp. 1-9.

[22]. Sharma, R., Sharma. S. \& Nagar, S. (2007). Extent of female school dropouts in Kangra District of Himachal Pradesh, Journal of Social Sciences. vol.15( 3), pp.201-204.

[23]. Sinha, S. (1998). The Gender Gap in Basic EducationNGOs As Change Agents, New Delhi: National Council Of Education Research, SAGE, p. 151.

[24]. Social and Rural Research Institute, MHRD, GOI (2009): All India Survey of Out-of-School Children of age 5 and in 6-14 years age group. Department of elementary education \& literacy, Retrieved on 27 June 2019 from https:// www.educationforallinindia.com/Survey-Reportof\%20out-of-School-Children- IMRB- MHRD-EDCil2009.
[25]. Suri, K. (2014). Education, conflict, and development: A case study of mobile schools for pastoralists in Jammu and Kashmir. IOSR Journal of Research \& Method in Education, vol.4(1), pp.12-19.

[26]. UNICEF-UIS (2014) 'All in School Global Initiative on Out-of-School Children: South Asia Regional Study', Kathmandu: UNICEF Regional Office. Retrieved from www.unicef.org/education/files/ South Asia_ OOSCI_ Study_ Executive_ Summary_26Jan_14Fi nal.pdf (accessed 10 January 2017).

[27]. Universal Declaration of Human Rights, Article 26. Retrieved from http://www.claiminghumanrights.org/education_defini tion.html 


\section{Manuscript Processing Footprints}

\section{A. Journal Volume/Issue Details}

This manuscript it published in Vol. 12 No. 012022 issue of IARS' International Research Journal (I'IRJ).

This is a Peer Reviewed (Refereed) International Journal published by IARS' Press Australia (International Association of Research Scholars) The Volume/Issue is a regular issue of the journal published in February 2022 Available at: https://researth.iars.info/index.php/curie.

\section{B. Copyright, License, and Publishing Rights}

- IARS' Press Australia (International Association of Research Scholars) respects the rights of the authors of research content published with IARS' International Research Journal. The "First Publication Rights" (FPR) to the original work accepted for publication at IARS' International Research Journal is granted to the Publisher of the Journal but copyright for all work published in the journal is retained by the author(s). Works published in the Journal is distributed under a Creative Commons Attribution 4.0 International License (CC BY 4.0). (This license lets others distribute, remix, adapt, and build upon your work, even commercially, as long as they credit you for the original creation. This is the most accommodating of licenses offered. Recommended for maximum dissemination and use of licensed materials.)

- After publishing the content with IARS' International Research Journal, the author holds complete right on the content for its amendments and reuse in any form. IARS' International Research Journal confirms that author(s) holds the copyright of the content.

- Author(s) grant(s) permission for their work to be indexed in part/full form in commercial and non-commercial indexes. Author(s) grant(s) permission for their work to be harvested in part/full form in commercial and non-commercial archives and distributed through them. Author(s) grant(s) permission for their work to be translated in part/full form in any language and republished and redistributed. Author(s) may enter into separate, additional contractual agreements for the non-exclusive distribution of the published version of the work, with an acknowledgement of its initial publication in this Journal.

- It is the responsibility of the author(s) to secure all necessary copyright and/or permissions for the use of third-party content in their manuscript(s). Author(s) have declared the same at the time of submission of manuscript and 'may also be required' to provide written evidence of this permission anytime in case required for any purposes.

- Publications Ethics and other Terms and Conditions as mentioned on official website of IARS' International Research Journal.

\section{Last Plagiarism Report}

SCREENED BY

$\checkmark$ iThenticate

Settings: Quotes Excluded, Bibliography Excluded

\begin{tabular}{|c|c|c|}
\hline $\begin{array}{l}\text { Parvaiz Ahmad Dar (Paper for IARS).docx } \\
1 \text { part - 3,962 words }\end{array}$ & $9 \%$ & Parvaiz \\
\hline
\end{tabular}

Exemption / Relaxation by Editor: None

\section{Processing Track}

\begin{tabular}{|l|l|}
\hline Date of Submission & 30 January 2022 \\
\hline Date of Final Review & 15 February 2022 \\
\hline Date of Acceptance \& Schedule & 27 February 2022 \\
\hline Date of Publishing & 28 February 2022 \\
\hline
\end{tabular}

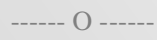

